\title{
Engineered Resistance Against Papaya ringspot virus in Venezuelan Transgenic Papayas
}

\author{
Gustavo Fermin, Valentina Inglessis, Cesar Garboza, Sairo Rangel, and Manuel Dagert, Department of Biology, \\ Universidad de Los Andes, Mérida, Venezuela; and Dennis Gonsalves, USDA - Pacific West Area, Pacific Basin Ag- \\ ricultural Research Center, Hilo, HI 96720
}

\begin{abstract}
Fermin, G., Inglessis, V., Garboza, C., Rangel, S., Dagert, M., and Gonsalves, D. 2004. Engineered resistance against Papaya ringspot virus in Venezuelan transgenic papayas. Plant Dis. $88: 516-522$

Local varieties of papaya grown in the Andean foothills of Mérida, Venezuela, were transformed independently with the coat protein (CP) gene from two different geographical Papaya ringspot virus (PRSV) isolates, designated VE and LA, via Agrobacterium tumefaciens. The CP genes of both PRSV isolates show 92 and $96 \%$ nucleotide and amino acid sequence similarity, respectively. Four PRSV-resistant R0 plants were intercrossed or selfed, and the progenies were tested for resistance against the homologous isolates VE and LA, and the heterologous isolates HA (Hawaii) and TH (Thailand) in greenhouse conditions. Resistance was affected by sequence similarity between the transgenes and the challenge viruses: resistance values were higher for plants challenged with the homologous isolates (92 to $100 \%$ similarity) than with the Hawaiian (94\% similarity) and, lastly, Thailand isolates (88 to $89 \%$ similarity). Our results show that PRSV CP gene effectively protects local varieties of papaya against homologous and heterologous isolates of PRSV.
\end{abstract}

Additional keywords: Carica papaya, post-transcriptional gene silencing, transgenic virus resistance

The concept of pathogen-derived resistance (32) gained support with the demonstration that expression of the coat protein (CP) gene of Tobacco mosaic virus (TMV) protected transgenic tobacco infected by TMV (28). Resistance in CP transgenetransformed plants can be mediated either by the protein (2) or by the transgene messenger (1). In CP-mediated resistance, the protein expressed in the transgenic plant can potentially interfere with the uncoating of incoming virus particles (41), or somehow impede replication $(26,27)$ or movement of the virus (42). In RNA-mediated resistance, the $\mathrm{CP}$ messenger and the challenging virus are degraded by a mechanism known as post-transcriptional gene silencing (1). RNA-mediated resistance is also referred to as homologydependent resistance since it is only functional against viruses whose $\mathrm{CP}$ genes share a high similarity with the transgene $(22-24,40)$. The strategy has been employed successfully to obtain viral resis-

Corresponding author: D. Gonsalves

E-mail: dgonsalves@pbarc.ars.usda.gov

Accepted for publication 24 December 2003.

Publication no. D-2004-0303-01R

This article is in the public domain and not copyrightable. It may be freely reprinted with customary crediting of the source. The American Phytopathological Society, 2004. tance in different plant crops, including fruit trees.

Papaya is a very popular fruit in the tropics and a reliable and cheap source of vitamins, but it is severely affected worldwide by Papaya ringspot virus (PRSV) (29). PRSV belongs to the Potyvirus genus of the Potyviridae family of plant viruses with a positive polarity RNA genome. The virus mRNA is translated into a polyprotein that is processed by proteases encoded in the viral genome to yield all products, including the coat protein $(34,36)$. In the late 1980s, papaya embryos were transformed with the $\mathrm{CP}$ gene cloned from the Hawaiian PRSV isolate HA 5-1 (11), resulting in two commercial cultivars, 'SunUp' and 'Rainbow', that were released to growers in Hawaii in 1998 (13). 'SunUp' is homozygous $(\mathrm{CP}+/ \mathrm{CP}+)$ for the PRSV HA 5-1 CP transgene, while 'Rainbow' is hemizygous $(\mathrm{CP}+/-)$ since it resulted from the cross between 'SunUp' and nontransgenic 'Kapoho' (20). The most popular cultivar, 'Rainbow', is susceptible to PRSV isolates outside Hawaii $(37,39)$.

The commercial production of papaya in Venezuela is being threatened by PRSV. Successful orchards are found only in places where the climatic conditions do not allow the proliferation of the aphid vector of the virus (21). Thus, in 1993, Venezuela started a technology transfer program with Cornell University aimed at transferring the transgenic technology using PRSV and papaya as a model system. Somatic embryos of a local papaya cultivar were transformed with the CP gene of two Venezuelan isolates of PRSV (8). In this paper, we describe the resistance of several transgenic R0 papayas and their progenies. We also analyze the range of their resistance against different isolates of the virus and report on the development of a transgenic product that completes the technology transfer program initiated 10 years ago.

\section{MATERIALS AND METHODS}

Cloning and engineering of the PRSV VE and LA CP genes. PRSV isolates were collected originally from infected papaya plants of commercial orchards near Mérida, Venezuela; PRSV EV was from El Vigía and PRSV LA from Lagunillas. The isolates were maintained as dried infected tissue or on young seedlings of Cucumis metuliferus and nontransgenic 'Sunrise' papaya. Reverse transcription (RT) reactions were performed as described previously (18). To amplify the sensetranslatable PRSV-CP genes, the following primers were used: the homologous primer JLS85， 5'-ATCATTCCATGGCTGTGGA TGCTGGTTTG-3' (the NcoI restriction site is shown underlined, which upon digestion creates a start codon that is indicated in bold), and the complementary JLS270 JLS86), 5'-AGC TAACCAT GGGTGAAACAGGGTCG-3' (35). Polymerase chain reaction (PCR) products of the expected size (ca. $1 \mathrm{~kb})$ were digested with NcoI and cloned into the cloning vector pGMM (43), a derivative plasmid of pBlueScript II SK(+), with the leader sequence of Cucumis mosaic virus (CMV). To allow for expression in planta, the cloned CP genes were subcloned into a plant expression cassette in vector pUC18cpexpress (35), thereby putting the transgene under the control of the $35 \mathrm{~S}$ double-enhancer promoter of Cauliflower mosaic virus (Fig. 1). After digestion with HindIII, the expression cassette was subcloned into the plant transformation vector pGA482G-identical to pGA482GG $(25,30)$ but without the uidA ( $\beta$ glucuronidase [GUS]) gene.

Plant material and transformation. 'Tailandia Roja' ('Thailand Red'), a local variety of papaya commercially cultivated in Mérida, Venezuela, was transformed with the PRSV LA and PRSV EV CP genes using a protocol reported previously 
(15). 'Tailandia Roja' is possibly a hybrid of different papaya cultivars grown in southwestern Mérida State. Somatic embryos were co-cultivated with a nononcogenic strain (LB4044) of Agrobacterium tumefaciens harboring a plant transformation vector with one of the two $\mathrm{CP}$ genes. Transformed embryos and nontransformed controls were incubated in the dark for 2 days and then transferred to agar media supplemented with kanamycin (150 $\mathrm{mg} / \mathrm{liter})$ and cefotaxime (500 $\mathrm{mg} / \mathrm{liter})$ or carbenicillin ( $250 \mathrm{mg} / \mathrm{liter})$. Plants resistant to kanamycin were those putatively transformed and able to express the gene of neomycin phosphotransferase II (NPTII). Regeneration and rooting of nontransformed and putatively transformed embryos were done as described previously (15).

Evaluation of R0 transgenic papaya and their progeny. Putatively transformed embryos were regenerated and rooted, established in greenhouse conditions in Venezuela, and then challenged with either PRSV VE or LA strains of the virus. Seeds were obtained from several resistant plants and used for further experiments at the New York State Agricultural Experiment Station (NYSAES), Cornell University, Geneva, NY. Seed-derived plants from self-fertilized transgenic R0 hermaphrodites and those from crosses between any combination of transgenic R0 male, female, and hermaphrodite papayas are referred to as R1 plants. Some of the R1 plants were allowed to produce seeds in Geneva, NY, and Mérida, Venezuela. Male plants were discarded, except for a few that were kept for crossing experiments. R1 females and hermaphrodites were crossed or self-fertilized (Table 1), and fruits and seeds were collected periodically. The term $\mathrm{R} 2$ refers to the progeny of selfed or crossed R1 plants.

Plant inoculation. Papaya seeds were sown in soil mix and transplanted to individual pots. Plants at the four true-leaf stage were inoculated with PRSV isolates HA (Hawaii) (14), LA (Lagunillas), EV (El Vigía), or TH (Thailand). The latter in our lab has a CP gene whose nucleotide sequence is very similar to other Thailand isolates reported elsewhere (17). Virus inoculum was prepared by macerating $1 \mathrm{~g}$ of infected leaves in $20 \mathrm{ml}$ of phosphate buffer $0.01 \mathrm{M}, \mathrm{pH} 7.5,0.1 \%$ sodium sulfite, and $10 \mathrm{mM}$ EDTA. Plants were dusted with Carborundum and the inoculum rubbed onto leaves with a pestle, $5 \mathrm{~min}$ after which leaves were rinsed with water. Plants were scored for symptoms on a weekly basis. Inoculated plants were considered resistant if they did not develop symptoms during the course of the experiment. The susceptible plants were also observed for symptom recovery until male plants started to flower, which happened 4 months after inoculation.

CP and NPTII detection. For NPTII protein detection, $40 \mathrm{mg}$ of transgenic and nontransgenic papaya leaves were tested in duplicate in at least two different enzymelinked immunosorbent assays (ELISAs) following the recommendations of the former manufacturers $\left(5^{\prime} \rightarrow 3^{\prime}\right.$ Inc., Boulder, $\mathrm{CO}$ ). The $\mathrm{CP}$ gene of transgenic plants harboring a sense, translatable construct was amplified using the primers JLS85 and JLS86 that were previously described. For the amplification of the nptII gene, the following primers were used: the homologous primer 5'-CCCCTCGGTATCCAA TTAGAG, and the complementary primer 5'-CGGGGGGTGGGCGAAGAACTCCAG (33). In reaction volumes of $100 \mu \mathrm{l}$, each PCR contained 0.1 to $0.2 \mu \mathrm{g}$ of genomic DNA, $100 \mathrm{ng}$ of each primer, $100 \mathrm{nM}$ of each deoxyribonucleotide, $2.5 \mathrm{mM} \mathrm{MgCl}_{2}$, and 2.5 units of Taq polymerase in its $1 \times$ commercial buffer (Promega, Madison, WI). After 1 min of "hot start" at $94^{\circ} \mathrm{C}$, DNA was added to the PCR tubes, after which the following program was used: denaturation at $94^{\circ} \mathrm{C}$ for $1 \mathrm{~min}$, annealing for $1 \mathrm{~min}$ at $55^{\circ} \mathrm{C}$ for $n p t I I$ and $62^{\circ} \mathrm{C}$ for $\mathrm{CP}$ gene, and extension at $72^{\circ} \mathrm{C}$ for $2 \mathrm{~min}$. All steps were repeated for 35 cycles. A final extension step at $72^{\circ} \mathrm{C}$ for $5 \mathrm{~min}$ ended the program. Every PCR assay was repeated with DNA samples from two independent isolations.

Southern and Northern assays. DNA and RNA from transgenic plants grown in the greenhouse were isolated according to published methods $(3,16)$ for Southern and Northern analysis $(7,31)$. Recommendations of the nylon membrane manufacturer (NEN Life Sciences Products, Boston, MA) were followed. The probe used for Southern and Northern analysis consisted of a purified and $\alpha{ }^{32} \mathrm{P}-\mathrm{dATP}-$ labeled PRSV EV CP gene.

DNA sequencing and analysis. DNA sequencing of the CP gene cloned from the Venezuelan isolates of PRSV, or from the genomic DNA of selected transformants, was done at the sequencing facility of NYSAES at Geneva, NY. In all cases, both DNA strands were sequenced (ABI Prism 373, Applied Biosystems, Foster City, CA) and analyzed by comparing the newly generated $\mathrm{CP}$ gene sequences with the ones in the GenBank database. Additionally, newly generated and known sequences of homologous and heterologous $\mathrm{CP}$ genes were aligned using the Laser-

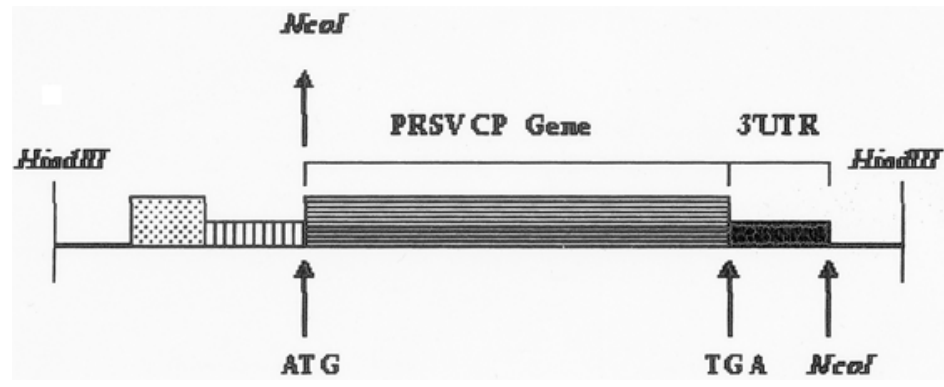

Fig. 1. Expression cassette in the expression vector pUC18cpexpress with the cloned coat protein (CP) gene of Papaya ringspot virus (PRSV), (horizontal lines). Amplified CP genes, including their 3' untranslatable region ( $\left.3^{\prime} \mathrm{UTR}\right)$, were digested with $\mathrm{NcoI}$ and cloned into pUC18cpexpress. The cloned $\mathrm{CP}$ gene is under the transcriptional control of the $35 \mathrm{~S}$ double-enhancer promoter of Cauliflower mosaic virus, (dots), and flanked by the $5^{\prime}$ untranslatable translational enhancer of Cucumber mosaic virus, (vertical lines), and the nopaline-synthase terminator, (solid). Upon digestion with HindIII, the expression cassette was subcloned into the plant transformation vector pGA482G. The start (ATG) and stop (TGA) codons of the cloned PRSV CP genes are indicated.

Table 1. Genetic characteristics of coat protein (CP)-transformed R0, R1, and R2 papaya plants that were selected for testing their resistance to various Papaya ringspot virus (PRSV) isolates

\begin{tabular}{|c|c|c|c|c|c|}
\hline \multirow{2}{*}{$\frac{\text { Generation }^{w}}{\text { R0: } \rightarrow}$} & \multicolumn{5}{|c|}{ Transgenic plant (CP transgene $)^{x}$, sex $^{y}$} \\
\hline & & $\begin{array}{l}\times \\
\downarrow\end{array}$ & T3 (EV), f & $\begin{array}{ll}\times & \mathrm{C} 1(\mathrm{EV}), \mathrm{h} \\
\downarrow & \end{array}$ & $\begin{array}{c}\mathrm{C} 2(\mathbf{E V}), \mathrm{h} \\
\downarrow\end{array}$ \\
\hline R1: $\rightarrow$ & \multicolumn{3}{|c|}{ Plants T2T3 ${ }^{\mathrm{z}}$} & Plants T3C1 (EV) & Plants C2C2 (EV) \\
\hline \multirow{7}{*}{ R1 crosses: } & 1 & & & & $\mathrm{C} 2 \mathrm{C} 2-40, \mathrm{~h}$ (selfed) \\
\hline & 2 & [3-34, f & $x$ & & $\mathrm{C} 2 \mathrm{C} 2-40, \mathrm{~h}$ \\
\hline & 3 & $3-47, \mathrm{~m}$ & $x$ & & $\mathrm{C} 2 \mathrm{C} 2-27, \mathrm{f}$ \\
\hline & 4 & {$[3-26, f$} & $x$ & $\mathrm{~T} 3 \mathrm{C} 1-31, \mathrm{~m}$ & \\
\hline & 5 & [3-26, f & $x$ & $\mathrm{~T} 3 \mathrm{C} 1-15, \mathrm{~m}$ & \\
\hline & 5 & & & $\mathrm{~T} 3 \mathrm{C} 1-15, \mathrm{~m}$ & $\mathrm{C} 2 \mathrm{C} 2-39, \mathrm{f}$ \\
\hline & 7 & {$[3-34, \mathrm{f}$} & $x$ & $\mathrm{~T} 3 \mathrm{C} 1-15, \mathrm{~m}$ & \\
\hline
\end{tabular}

${ }^{\text {w}}$ Only R1 individuals used for selected R1 crosses are shown. Resistant individuals from the three R1 groups were selfed (e.g., C2C2-40) or intercrossed (e.g., T2T3-34 $\times \mathrm{C} 2 \mathrm{C} 2-40)$ to obtain the R2 populations.

${ }^{x}$ EV stands for the CP gene isolated from PRSV EV (El Vigía), and LA for the one isolated from PRSV LA (Lagunillas).

${ }^{y} \mathrm{f}$ stands for female, $\mathrm{m}$ for male, and $\mathrm{h}$ for hermaphrodite.

${ }^{\mathrm{z}}$ We did not establish if these plants were harboring the LA or EV, or both LA and EV transgenes. 
Gene software (DNAStar, Madison, WI). The sequences of the $\mathrm{CP}$ genes of the isolates LA, EV, and TH were generated in D. Gonsalves' lab and have not been published. Sequences for the complete genome of the HA isolate are available at the GenBank database as X67673 and S46722.

\section{RESULTS}

Papaya transformation with the CP gene of two Venezuelan isolates of PRSV and characterization of $\mathrm{RO}$ plants. Recombinant plasmids harboring the $\mathrm{CP}$ gene of two Venezuelan isolates were delivered to papaya somatic embryos by transformation using A. tumefaciens. Efficiency of regeneration was very low, and only a few kanamycin-resistant transgenic plants were obtained (V. Inglessis, unpublished results). Surprisingly, despite the stringent conditions of selection in medium amended with kanamycin, the regenerated R0 plants showed no evidence of NPTII protein production, according to ELISA results. However, the CP gene was amplifiable by PCR and detected by Southern analysis (data not shown). PCR amplification under stringent conditions resulted in only one band of the expected size (Fig. 2), and sequencing of the purified PCRproduct corroborated that it was, in fact, the PRSV CP gene (9).

From three independent transformation experiments, five PRSV-resistant transgenic R0 plants (T2, T3, C1, C2, and C3) were identified and allowed to flower, but only the first four were analyzed here (Table 1). Plants $\mathrm{C} 1$ and $\mathrm{C} 2$ were hermaphrodites, T2 was male and T3 was female. Plant T2 contains the $\mathrm{CP}$ gene of PRSV LA, while plants T3, C1, and C2 contain the CP gene from PRSV EV. All plants were resistant to three serial inoculations (one every 8 days) with PRSV LA under greenhouse conditions in Mérida, Venezuela. Transgenic hermaphrodites were

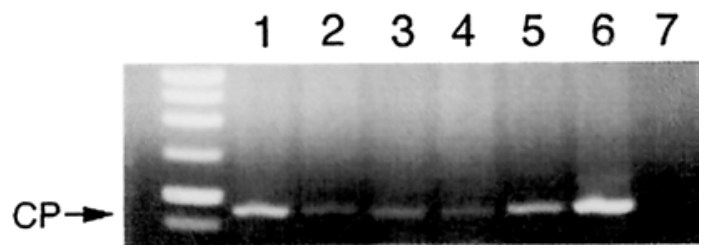

Fig. 2. Amplification by polymerase chain reaction (PCR) of the coat protein $(\mathrm{CP})$ gene from genomic DNA of R0 transformed papaya plants. 1, C1; 2, C2; 3, C3; 4, T2; 5, T3; 6, CP-transgenic 'Rainbow' papaya; 7, nontransgenic 'Sunrise' papaya. Arrow indicates the position of the CP gene PCRgenerated band.

Table 2. Reaction of R1 Papaya ringspot virus (PRSV) coat protein (CP) gene transgenic papaya plants $^{\mathrm{x}}$ challenged with different geographical isolates of PRSV (Geneva, NY, 1999)

\begin{tabular}{|c|c|c|c|c|c|c|c|}
\hline \multirow[b]{3}{*}{ R0 crosses } & \multirow[b]{3}{*}{$\mathbf{C P}$} & \multicolumn{6}{|c|}{ Reactions $^{y}$ to inoculations with PRSV isolates ${ }^{z}$} \\
\hline & & \multicolumn{2}{|c|}{ PRSV EV } & \multicolumn{2}{|c|}{ PRSV LA } & \multicolumn{2}{|c|}{ PRSV HA } \\
\hline & & Resistant & $\%$ & Resistant & $\%$ & Resistant & $\%$ \\
\hline $\mathrm{T} 2 \times \mathrm{T} 3$ & LA-EV & $0 / 16$ & 0 & $5 / 16$ & 31 & $6 / 16$ & 38 \\
\hline $\mathrm{T} 3 \times \mathrm{C} 1$ & EV & $1 / 15$ & 7 & $11 / 15$ & 73 & $9 / 15$ & 60 \\
\hline C2 selfed & EV & $0 / 15$ & 0 & $7 / 14$ & 50 & $7 / 14$ & 50 \\
\hline Totals & & $1 / 46$ & 2 & $23 / 45$ & 51 & $22 / 45$ & 49 \\
\hline Nontransgeni & & $0 / 2$ & 0 & $0 / 2$ & 0 & $0 / 2$ & 0 \\
\hline
\end{tabular}

${ }^{x}$ Plants were scored weekly after inoculation; the results shown here were scored 2 months after inoculation. Resistant plants are those that never showed symptoms, not even chlorotic, isolated spots.

${ }^{y}$ Number of plants resistant over number of plants inoculated.

${ }^{\mathrm{z}}$ EV refers to the PRSV virus isolate and the PRSV CP gene from El Vigía, LA from Lagunillas (Venezuela), and HA from Hawaii.

Table 3. Reaction of R1 Papaya ringspot virus (PRSV) coat protein gene transgenic papaya plants that were resistant to a first inoculation ${ }^{\mathrm{z}}$ and subsequently challenged with PRSV EV for a second and a third time (Geneva, NY, 1999)

\begin{tabular}{|c|c|c|c|c|c|c|}
\hline \multirow[b]{3}{*}{ Selected R1 plants from: } & \multicolumn{6}{|c|}{ EV-resistant/no. inoculated } \\
\hline & \multicolumn{2}{|c|}{ EV-resistant ${ }^{\mathrm{z}}$} & \multicolumn{2}{|c|}{ LA-resistant ${ }^{\mathrm{z}}$} & \multicolumn{2}{|c|}{ HA-resistant ${ }^{\mathrm{z}}$} \\
\hline & 2nd & 3rd & 2nd & 3rd & 2nd & 3rd \\
\hline $\mathrm{T} 2 \times \mathrm{T} 3$ & NA & NA & $3 / 5$ & $3 / 3$ & $3 / 6$ & $3 / 3$ \\
\hline $\mathrm{T} 3 \times \mathrm{C} 1$ & $1 / 1$ & $1 / 1$ & $4 / 11$ & $2 / 4$ & $3 / 9$ & $3 / 3$ \\
\hline C2 selfed & NA & NA & $4 / 7$ & $2 / 4$ & $4 / 7$ & $2 / 4$ \\
\hline Totals & $1 / 1$ & $1 / 1$ & $11 / 23$ & $7 / 11$ & $10 / 22$ & $8 / 10$ \\
\hline Nontransgenic 'Sunrise' & $0 / 2$ & $0 / 2$ & $0 / 2$ & $0 / 2$ & $0 / 2$ & $0 / 2$ \\
\hline
\end{tabular}

${ }^{\mathrm{z}}$ Refer to Table 2 for the origin of plants resistant to the first inoculation. Plants were scored weekly after inoculation; the results shown here were scored 2 months after inoculation. Resistant plants are those that never showed symptoms, not even chlorotic, isolated spots. NA: not applicable. crossed with a transgenic female papaya or self-fertilized, and the same female was crossed with a transgenic male, to obtain the first test (R1) generation (Table 1).

Reaction of R1 CP-transgenic papaya to inoculation with PRSV LA, EV, and HA strains. Seeds from the R0 crosses shown in Table $1(\mathrm{~T} 2 \times \mathrm{T} 3, \mathrm{~T} 3 \times \mathrm{C} 1$, and $\mathrm{C} 2 \times \mathrm{C} 2$ ) were sown, and plantlets were tested for NPTII and inoculated with three isolates of PRSV. All of the 146 test plants were negative for NPTII by ELISA, and amplification by PCR from 20 plants also failed to detect the nptII gene. Thus, plants chosen for further analysis were selected based on their resistance against different geographical isolates of PRSV. After assessing resistance, plants were further characterized for the presence of the $\mathrm{CP}$ gene, initially by PCR; but those selected for crosses to obtain an R2 generation were also analyzed by Southern and Northern hybridization assays.

Inoculations done at Geneva, NY, are summarized in Table 2. Only one of the 46 inoculated R1 plants showed resistance to PRSV EV. This male plant, T3C1-15, from the cross $\mathrm{T} 3 \times \mathrm{C} 1$, was used in subsequent crosses to obtain R2 plants after checking its transgenic status by PCR and Southern analysis. In contrast, inoculations with PRSV LA identified a higher number of resistant plants in the progenies from the crossed and selfed R0 plants. Interestingly, inoculations with PRSV HA revealed a similar number of resistant plants to those observed for PRSV LA inoculations. Resistant plants did not show any symptoms of infection.

Inoculation experiments were also done in Mérida, Venezuela. Forty-seven percent (28 of 59 plants) of the progeny from the cross T2 $\times$ T3 were resistant to inoculations with PRSV LA. Resistance was also observed in $53 \%$ (35 of 66) of the R1 plants derived from the cross $\mathrm{C} 2 \times \mathrm{C} 2$. Furthermore, nontransgenic papaya scions were grafted to four individual R0 C2 clones. The rootstocks were inoculated with PRSV LA, but scions did not develop symptoms after several months of observation.

R1 Plants that showed resistance to PRSV EV, LA, or HA after the first inoculation in Geneva (Table 2) were challenged a second time with PRSV EV (Table 3). About half of the challenged plants showed resistance. For example, 11 of the 23 LA-resistant plants were resistant to $\mathrm{EV}$, and 10 of the $22 \mathrm{HA}$-resistant plants were resistant to EV. The resistant plants were then challenged a third time with PRSV EV (Table 3) when they were at the flowering stage. All six R1 plants of the T2 $\times$ T3 group that showed resistance to LA and $\mathrm{HA}$ in the second inoculation also showed resistance to EV (Fig. 3). In contrast, a number of T3 $\times \mathrm{C} 1$ and $\mathrm{C} 2 \times \mathrm{C} 2$ plants (6 of 15) that were resistant to LA and HA in the second inoculation were 
susceptible to a subsequent inoculation with EV.

After data on symptom reaction were collected, the resistant plants were kept for
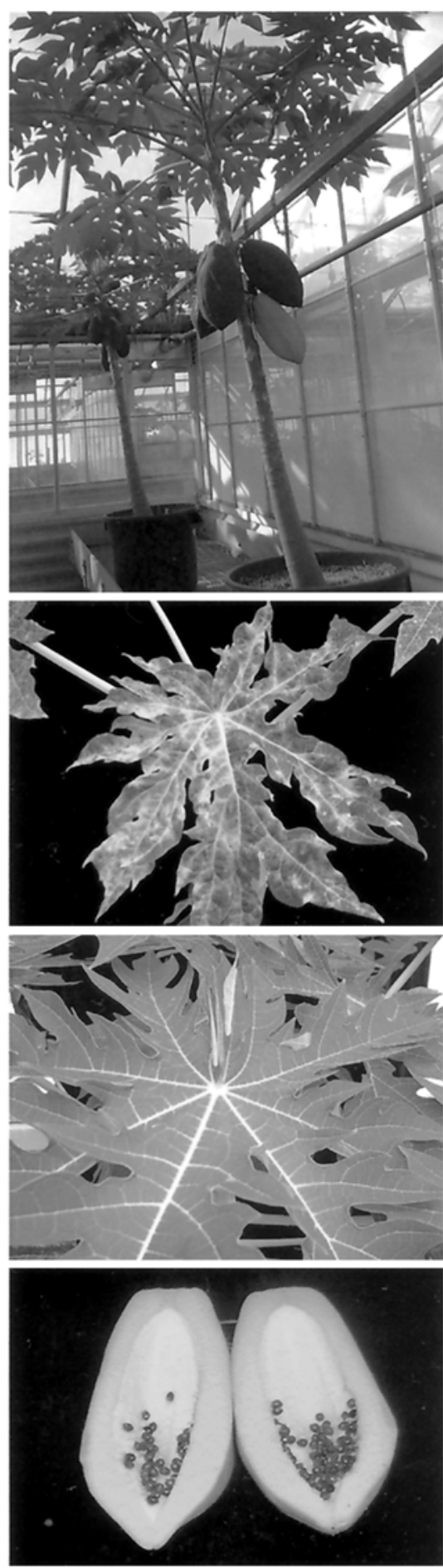

Fig. 3. From top to bottom: first, a hermaphrodite transgenic papaya, $\mathrm{C} 2 \mathrm{C} 2-40$, after three cycles of inoculation (plant was discarded after 2 years of experiments, and it never showed symptoms); second, leaf from a susceptible transgenic papaya showing clear mosaic symptoms of infection by Papaya ringspot virus; third, leaf from a healthy transgenic papaya after 3 cycles of inoculations with PRSV LA, $\mathrm{EV}$, and $\mathrm{EV}$; and fourth, close-up of a fruit derived from $\mathrm{C} 2 \mathrm{C} 2-40$. extended periods to obtain seeds. We observed that some plants scored as resistant developed mild symptoms that disappeared after about a month.

Reaction of R2 CP-transgenic plants to inoculation with PRSV EV, HA, and TH strains. Seven crosses (Table 4) were performed with the $\mathrm{R} 1$ papaya plants that showed resistance to a second and third inoculation with PRSV EV (Tables 1 and 3). Two of the crosses had only the EV CP gene, while the remaining five had a combination of EV and LA genes. All plants used for crosses tested positive for the CP gene by PCR and Southern analysis. We challenged R2 plants with the EV (Venezuela), HA (Hawaii), and TH (Thailand) isolates of PRSV (Table 4). Similarity values for the nucleotide and amino acid sequences of the $\mathrm{CP}$ gene are shown in Table 5.

In general, about one-third of the population from the majority of the crosses was resistant to the EV isolate (Table 4). The progeny from a selfed transgenic papaya plant (C2C2-40) had the lowest percentage (22\%) of resistant plants to $\mathrm{EV}$, and progenies of the T2T3-34 $\times$ C2C2-40 and C2C2$27 \times$ T2T3-47 crosses, the highest ones (45 and $55 \%$, respectively). Resistance to the non-homologous HA isolate was high (more than $50 \%$ in most crosses) in all tested populations, with the exception of the selfed $\mathrm{C} 2 \mathrm{C} 2-40$, in which only onethird of the individuals were resistant. The $\mathrm{R} 2$ plants showed the lowest resistance to the $\mathrm{TH}$ isolate. Four populations showed 20 to $27 \%$ resistance, two about $12 \%$, and one $8 \%$. Interestingly, selfed $\mathrm{C} 2 \mathrm{C} 2-40$ descendants showed similar resistance (22 to $33 \%$ ) to all three isolates.
Selected R2 plants were analyzed further. PRSV EV-resistant R2 plants were divided into two groups and challenged with the isolates $\mathrm{TH}$ and HA (Table 6). Since a more diverse range of symptomatic responses was observed, the reactions were rated as susceptible with severe (I) or mild leaf distortion (II), and resistant with few isolated chlorotic spots on leaves (III), or symptomless (IV). In general, similar proportions of plants were resistant to PRSV $\mathrm{TH}$ or HA. It was also observed that the susceptible R2 plants showed milder symptoms than the susceptible R1 plants that were inoculated with PRSV TH or HA. Descendants from some crosses had a mixture of susceptible and resistant plants (e.g., T2T3-26 × T3C1-15), while those from $\mathrm{C} 2 \mathrm{C} 2-40(\mathrm{C} 2 \mathrm{C} 2-40$ selfed and T2T3$34 \times \mathrm{C} 2 \mathrm{C} 2-40$ ) were all resistant, except for one plant.

Southern and Northern analyses of the R0 and R1 generations. The Southern hybridization using the $\mathrm{CP}$ gene as a probe revealed only one band of high molecular weight in the $B g l I I$-digested genomic DNA of putatively transformed papayas (Fig. 4, panel A). The analyzed R0 and R1 plants, including the ones used to make the crosses that gave origin to the R2 population, all showed one band of similar size. This suggests that all R0 plants initially harbored only one insertion, since genomic DNA was digested with a restriction enzyme that does not cut the transformation vector or the engineered $\mathrm{CP}$ genes.

The R1 plants, however, exhibited appreciable differences in the level of cytoplasmic CP mRNA, regardless of the level of resistance to PRSV (Fig. 4, panel B).

Table 4. Summary of infection results of R2 Papaya ringspot virus (PRSV) coat protein (CP) transgenic papaya plants ${ }^{\mathrm{y}}$ challenged with different geographical isolates of PRSV (Geneva, NY, 2001)

\begin{tabular}{lccccccc}
\hline & & \multicolumn{5}{c}{ No. resistant/No. inoculated plants per isolate ${ }^{z}$} \\
\cline { 3 - 7 } Cross & CP & PRSV EV & $\%$ & PRSV HA & $\%$ & PRSV TH & $\%$ \\
\hline C2C2-40 selfed & EV & $7 / 32$ & 22 & $4 / 12$ & 33 & $5 / 18$ & 28 \\
T2T3-34 $\times$ C2C2-40 & EV-LA & $13 / 29$ & 45 & $8 / 15$ & 53 & $3 / 15$ & 20 \\
T2T3-34 $\times$ T3C1-15 & EV & $6 / 21$ & 29 & $10 / 18$ & 56 & $1 / 12$ & 8 \\
C2C2-39 $\times$ T3C1-15 & EV & $10 / 31$ & 32 & $8 / 15$ & 53 & $2 / 16$ & 13 \\
T2T3-26 $\times$ T3C1-15 & EV-LA & $10 / 30$ & 33 & $13 / 21$ & 62 & $6 / 24$ & 25 \\
T2T3-26 $\times$ T3C1-31 & EV-LA & $10 / 32$ & 31 & $9 / 18$ & 50 & $3 / 12$ & 25 \\
C2C2-27 $\times$ T2T3-47 & EV-LA & $17 / 31$ & 55 & $10 / 15$ & 67 & $2 / 15$ & 13 \\
\hline
\end{tabular}

y Resistant plants are those that never developed symptoms, not even chlorotic, isolated spots.

${ }^{\mathrm{z}}$ EV refers to the PRSV isolate from El Vigía (Venezuela), HA from Hawaii, and TH from Thailand.

Table 5. Percent similarity among the coat protein sequences of the Papaya ringspot virus isolates used in this work, by pairwise analysis

\begin{tabular}{ccccc}
\hline & \multicolumn{4}{c}{ Nucleotide sequences $^{\mathbf{z}}$} \\
\cline { 2 - 4 } Amino acid sequences $^{\mathbf{z}}$ & EV & LA & TH & HA \\
\hline EV & & 92 & 88 & 94 \\
LA & $93(96)$ & & 89 & 94 \\
TH & $92(97)$ & $92(95)$ & & 90 \\
HA & $95(98)$ & $96(97)$ & $95(96)$ & \\
\hline
\end{tabular}

y EV refers to the isolate PRSV EV (El Vigía), LA to PRSV LA (Lagunillas), TH to PRSV TH (Thailand), and HA to PRSV HA (Hawaii).

${ }^{\mathrm{z}}$ For nucleotide sequence comparisons, the values of similarity refer to percentage of nucleotide identities; while amino acid sequence comparisons refer to percentage of amino acid identities, followed by the corresponding values of amino acid similarities in parentheses. 
For example, plants C2C2-39 (female, lane 3, panel B) and C2C2-40 (hermaphrodite, lane 4, panel B) were derived from the same cross and were resistant to the isolate LA (first inoculation), but the level of CP mRNA for C2C2-40 was almost undetectable, while it was very conspicuous for C2C2-39. Only C2C2-40 was resistant to two further inoculations with PRSV EV.

The level of mRNA accumulation did not strictly correlate with resistance against PRSV. Some plants with low levels of mRNA accumulation showed a high level of resistance since they did not show symptoms during the length of the observation period that lasted for more than a year (C2C2-40, T3C1-15, and $\mathrm{T} 3 \mathrm{C} 1-34$, lanes 4,8 , and 10, panel B). In contrast, all HA-resistant plants (first inoculum) that also showed resistance to EV upon second inoculation accumulated a fairly high level of $\mathrm{CP}$ mRNA and/or challenging virus (lanes 2, 5, 9, and 11, panel B).

\section{DISCUSSION}

We have obtained and characterized transgenic papaya plants transformed with the sense/translatable $\mathrm{CP}$ gene from two different Venezuelan isolates of PRSV in independent transformation experiments. This is the first report of a transgenic fruit crop obtained in Venezuela. These transgenic papayas showed resistance to the Venezuelan isolates EV and LA, and to one isolate each from Hawaii (HA) and Thailand (TH).

Either the transgene mRNA or its product could play a role in conferring resistance against different isolates of PRSV. Although we have no data on the detection of the protein in planta, in vitro experiments showed that the $\mathrm{CP}$ transgene could be transcribed and translated (8). Several observations, however, support the idea that resistance is RNA-mediated. First, the dependence between transgenic resistance and sequence similarity has been previously demonstrated for transgenic 'Rainbow' papaya expressing a translatable PRSV HA CP gene (39). PRSV-resistant transgenic papayas, expressing an untrans- latable CP gene, also show resistance only against isolates of PRSV highly related to the transgene by sequence similarity (12; and D. Gonsalves, G. Fermin, and C. Gonsalves, unpublished results). Second, resistance in the Venezuelan papayas was higher against challenge isolates (LA, EV, HA) whose CP genes showed higher nucleotide sequence similarity to the $\mathrm{CP}$ transgene(s). Finally, a number of resistant plants showed barely detectable levels of cytoplasmic CP transgene mRNA (Fig. 4). R2 plants of different crosses showed a more homogeneous, low level of the transgene mRNA regardless of the level of expression in the progenitor plants (data not shown). In other words, the lowest level of transgene RNA detection in transgenic plants whose insertions were stabilized by meiosis supports the RNA-mediated mechanism of resistance.

Plants transformed with the EV CP gene showed no resistance to the homologous isolate of the virus in the R1 generation (first inoculation), except for one plant. Yet, after introducing the EV transgene into papaya by crossing with the male $\mathrm{T} 3 \mathrm{C} 1-15$, we were able to obtain a fairly high level of resistance in the descendants, which argues against the possibility that this very transgene (EV) is not as effective in conferring resistance to papaya as the other PRSV CP transgene (LA). The most plausible explanation, thus, is that the initial screening for resistance in the R0 generation, performed exclusively with the LA transgene, introduced a biased selection in favor of resistance against PRSV LA. An-
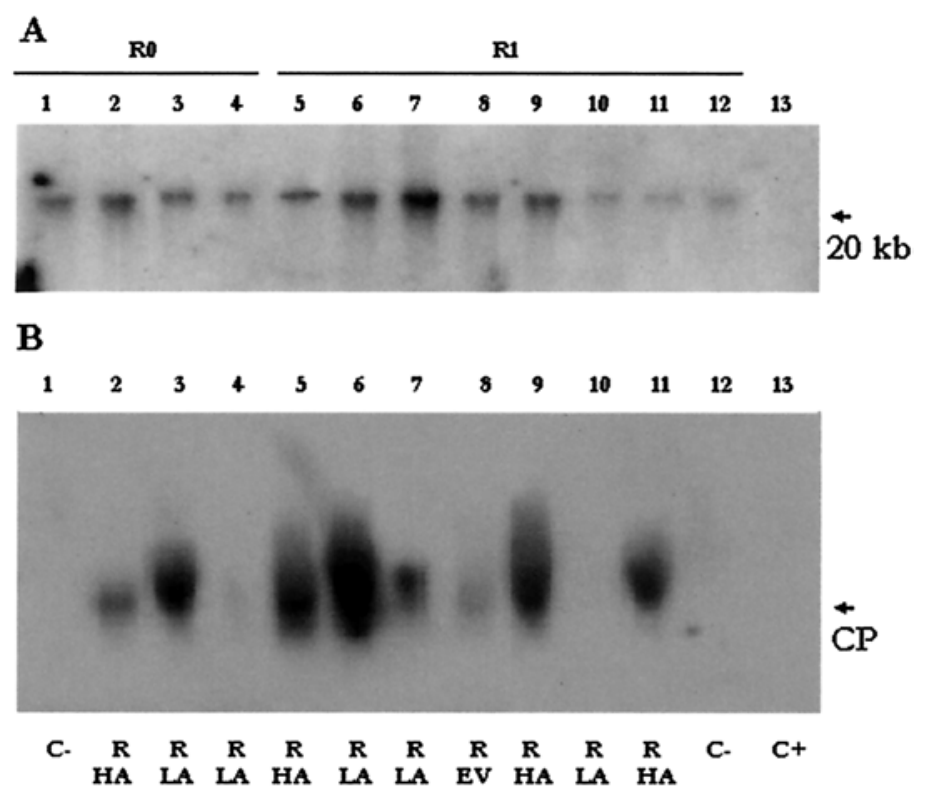

Fig. 4. Southern and Northern analyses of selected transgenic papaya plants. A radioactively labeledcoat protein $(\mathrm{CP})$ gene was used to detect immobilized DNA or RNA from different transgenic plants.

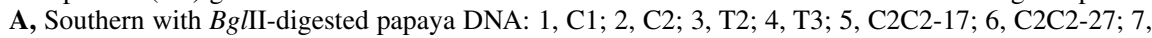
C2C2-39; 8, C2C2-40; 9, T2T3-26; 10, T2T3-34; 11, T2T3-47; 12, T3C1-15; 13, Nontransgenic 'Sunrise'. B, Northern with selected plants: 1, Nontransgenic 'Sunrise'; 2, C2C2-27; 3, C2C2-39; 4, C2C2-40; 5, T2T3-26; 6, T2T3-34; 7, T2T3-47; 8, T3C1-15; 9, T3C1-26; 10, T3C1-34; 11, C2C2-17; 12, 'Rainbow' hemizygous $\mathrm{CP}+/-$ papaya; 13, nontransgenic Cucumis metuliferus. RNA from samples 2 to 11 were obtained after inoculation with the isolate indicated below the figure.

Table 6. Reaction of R2 Papaya ringspot virus (PRSV) EV-resistant transgenic papaya plants ${ }^{\mathrm{z}}$ reinoculated with heterologous strains of PRSV (Geneva, NY, 2001)

\begin{tabular}{|c|c|c|c|c|c|c|c|c|c|}
\hline \multirow[b]{4}{*}{ Cross } & \multirow[b]{4}{*}{$\mathbf{C P}$} & \multicolumn{8}{|c|}{ Reaction to second inoculum (no. of plants) } \\
\hline & & \multicolumn{4}{|c|}{ PRSV TH } & \multicolumn{4}{|c|}{ PRSV HA } \\
\hline & & \multicolumn{2}{|c|}{ Susceptible } & \multicolumn{2}{|c|}{ Resistant } & \multicolumn{2}{|c|}{ Susceptible } & \multicolumn{2}{|c|}{ Resistant } \\
\hline & & $\mathbf{I}$ & II & III & IV & $\mathbf{I}$ & II & III & IV \\
\hline C2C2-40 selfed & EV & - & - & 3 & 1 & - & 1 & 2 & - \\
\hline $\mathrm{T} 2 \mathrm{~T} 3-34 \times \mathrm{C} 2 \mathrm{C} 2-40$ & EV-LA & - & - & 6 & 1 & - & - & 5 & 1 \\
\hline Т2Т3-34 × T3C1-15 & EV & 2 & 1 & - & - & - & - & - & 3 \\
\hline $\mathrm{C} 2 \mathrm{C} 2-39 \times \mathrm{T} 3 \mathrm{C} 1-15$ & $\mathrm{EV}$ & 1 & 2 & 2 & _- & - & 3 & 2 & - \\
\hline Т2T3-26 × T3C $1-15$ & EV-LA & 2 & 1 & 1 & 1 & 1 & 1 & 2 & 2 \\
\hline T2T3-26 × T3C $1-31$ & EV-LA & - & 6 & - & _- & - & 2 & 2 & - \\
\hline $\mathrm{C} 2 \mathrm{C} 2-27 \times$ T2T3-47 & EV-LA & - & 3 & 4 & 1 & 1 & 5 & 3 & - \\
\hline
\end{tabular}

${ }^{\mathrm{z}}$ Plants used for this experiment are the PRSV EV-resistant individuals of Table 4. Symptoms were classified as I, severe (rolled, chlorotic, and deformed leaves); II mild (some extensive deformation of at least one leaf, but not all); III (few chlorotic spots in well-developed leaves); and IV (no signs of virus infection). 
other possibility is that both transgenes have most probably inserted in different genomic locations, which in turn might lead to different levels of expression.

The differences in protection observed in our transgenic plants when analyzed by generation and source of inoculum may be due to transgene dosage, which plays a fundamental role in the phenotypic manifestation of resistance in transgenic papayas $(19,39)$. We did not establish here, however, what proportion of the R2 population was homozygous or double hemizygous for the CP transgene(s). We expect to identify a homozygous line from the third generation that we are currently analyzing. It might also be that PRSV EV possesses a greater capacity to counteract posttranscriptional gene silencing. It has been reported that HC-Pro, a potyvirus protein with multiple activities, can suppress gene silencing (4). Infectious cDNA clones of PRSV HA have been developed (6), and chimeric viruses with different $\mathrm{CP}$ genes in a PRSV HA genome backbone have been created (5). Thus, it would be interesting to determine if PRSV HA recombinant virus with the HC-Pro of PRSV EV would show increased virulence on transgenic papayas with the CP transgene of PRSV HA (e.g., 'Rainbow') or the transgenic papayas developed in this work.

Other countries have engineered their own transgenic papayas resistant to the local isolate of the virus $(10,13,19,38)$, and some are ready to make transgenic seeds available to papaya growers (P. Tennant, personal communication). Thanks to a collaborative effort with Cornell University that started almost 10 years ago, the transgene technology has been transferred, and a transgenic product has been obtained in the background of 'Tailandia Roja'-a papaya well adapted to Venezuela conditions, highly accepted by big and small farmers and consumers, and endowed with desirable agronomic characteristics that include smooth and sweet flesh of the fruits, and high fertility.

\section{ACKNOWLEDGMENTS}

We thank the greenhouse crew and all members of the Department of Plant Pathology of the New York State Agricultural Experiment Station for its constant support and technical assistance. This project was partially financed by BID-CONICIT and CDCHT-ULA, and it was also a part of G. Fermin's doctoral thesis at Cornell University.

\section{LITERATURE CITED}

1. Baulcombe, D. 1996. RNA as a target and initiator of post-transcriptional gene silencing in transgenic plants. Plant Mol. Biol. 32:79-88.

2. Beachy, R. 1990. Coat protein-mediated resistance against virus infection. Annu. Rev. Phytopathol. 28:451-474.

3. Cabrera-Ponce, J., Vegas-Garcia, A., and Herrera-Estrella, L. 1995. Herbicide-resistant transgenic plants produced by an efficient particle bombardment transformation method. Plant Cell Rep. 15:1-7.

4. Carrington, J., Kasschau, K., and Johansen, L. 2001. Activation and suppression of RNA silencing by plant viruses. Virology 281:1-5.
5. Chiang, C.-H., Wang, J.-J., Jan, F.-J., Yeh, S.D., and Gonsalves, D. 2001. Comparative reactions of recombinant Papaya ringspot viruses with chimeric coat protein $(\mathrm{CP})$ genes and wild-type viruses on CP-transgenic papaya. J. Gen. Virol. 82:2827-2836.

6. Chiang, C.-H., and Yeh, S.-D. 1997. Infectivity assays of in vitro and in vivo transcripts of $\mathrm{Pa}$ paya ringspot potyvirus. Bot. Bull. Acad. Sinica 38:153-163.

7. Feinberg, A., and Vogelstein, B. 1983. A technique for radiolabeling DNA restriction endonuclease fragments to high specific activity. Anal. Biochem. 132:6-13.

8. Fermin, G. 1996. Análisis molecular de variantes geográficos del virus de la mancha anular de la lechosa (PRV) y cloneo de diversos constructos. M.S. thesis. Universidad de Los Andes, Mérida.

9. Fermin-Munoz, G. 2002. Use, application, and technology transfer of native and synthetic genes to engineering single and multiple transgenic viral resistance. Ph.D. thesis. Cornell University, Ithaca, NY.

10. Ferreira, S. A., Pitz, K. Y., Manshardt, R., Zee, F., Fitch, M., and Gonsalves, D. 2002. Virus coat protein transgenic papaya provides practical control of Papaya ringspot virus in Hawaii. Plant Dis. 86:101-105.

11. Fitch, M., Manshardt, R., Gonsalves, D., Slightom, J., and Sanford, J. 1992. Virus resistant papaya derived from tissues bombarded with the coat protein gene of Papaya ringspot virus. Bio/Technol. 10:1466-1472.

12. Gonsalves, C., Cai, W., Tennant, P., and Gonsalves, D. 1998. Effective development of $P a$ paya ringspot virus resistant papaya with untranslatable coat protein gene using a modified microprojectile transformation method. Acta Hortic. 461:311-314.

13. Gonsalves, D. 1998. Control of Papaya ringspot virus in papaya: A case study. Annu. Rev. Phytopathol. 36:415-437.

14. Gonsalves, D., and Ishii, M. 1980. Purification and serology of papaya ringspot virus. Phytopathology 70:1028-1032.

15. Inglessis, M., Vielma, M., Dagert, M., Contreras, I., and Herrera-Estrella, L. 1997. Preliminary studies for an efficient regeneration and transformation of Carica papaya L. var. Thailand red. Acta Cient. Venez. 48:154-159.

16. Jorgensen, R., Cluster, P., English, J., Que, Q., and Napoli, C. 1996. Chalcone synthase cosuppression phenotypes in petunia flowers: Comparison of sense vs. antisense constructs and single copy vs. complex T-DNA sequences. Plant Mol. Biol. 31:957-973.

17. Kertbundit, S., Attasart, P., Panyim, S., and Juricek, M. 1998. Sequence comparison of coat protein and $3^{\prime}$ non-translated region of papaya ringspot virus isolates from Thailand. Asia-Pac. J. Mol. Biol. 6:191-197.

18. Levy, L., Lee, I.-M., and Hadidi, A. 1994. Simple and rapid preparation of infected plant tissue extracts for PCR amplification of virus, viroid, and MLO nucleic acids. J. Virol. Methods 49:295-304.

19. Lines, R., Persley, D., Dale, J., Drew, R., and Bateson, M. 2002. Genetically engineered immunity to Papaya ringspot virus in Australian papaya cultivars. Mol. Breeding 10:119129.

20. Manshardt, R. 1998. 'UH Rainbow' papaya. University of Hawaii, College of Tropical Agriculture and Human Resources. Germplasm, Honolulu: G-1-2.

21. Marys, E., Carballo, O., and IzaguirreMayoral, M. 2000. Occurrence and relative incidence of viruses infecting papaya in Venezuela. Ann. Appl. Biol. 136:121-124.

22. Matzke, M., Matzke, A., Pruss, G., and Vance, V. 2001. RNA-based silencing strategies in plants. Curr. Opin. Genet. Dev. 11:221-227.

23. Meyer, P. 1996. Homology-dependent gene silencing in plants. Annu. Rev. Plant Physiol. 47:23-48

24. Mueller, E., Gilbert, J., Davenport, G., Brigneti, G., and Baulcombe, D. 1995. Homology-dependent resistance: Transgenic virus resistance in plants related to homologydependent gene silencing. Plant J. 7:10011013.

25. Namba, S., Ling, K., Gonsalves, C., Gonsalves, D., and Slightom, J. 1991. Expression of the gene encoding the coat protein of $\mathrm{Cu}$ cumber mosaic virus (CMV) strain WL appears to provide protection to tobacco plants against infection by several different CMV strains. Gene 107:181-188.

26. Nelson, R., Powell-Abel, P., and Beachy, R. 1987. Lesion and virus accumulation in inoculated transgenic tobacco plants expressing the coat protein gene of Tobacco mosaic virus. Virology 158:126-132.

27. Osbourn, J., Watts, J., and Beachy, R. 1989. Evidence that nucleocapsid disassembly and a later step in virus replication are inhibited in transgenic tobacco expressing TMV coat protein. Virology 172:370-373.

28. Powell-Abel, P., Nelson, R., De, B., Hoffman, N., Rogers, S., Fraley, R., and Beachy, R. 1986. Delay of disease development in transgenic plants that express the Tobacco mosaic virus coat protein gene. Science 232:738-743.

29. Purcifull, D., Edwardson, J., Hiebert, E., and Gonsalves, D. 1984. Papaya ringspot virus. No 292 in: Descriptions of Plant Viruses. Commonw. Mycol. Inst./Assoc. Appl. Biol., Kew, Surrey, England.

30. Quemada, H. D., Gonsalves, D., and Slightom, J. L. 1991. Expression of coat protein gene from cucumber mosaic virus strain $\mathrm{C}$ coat in tobacco: Protection against infections by CMV strains transmitted mechanically or by aphids. Phytopathology 81:794-802.

31. Sambrook, J., Fritsch, E., and Maniatis, T. 1989. Molecular Cloning: A Laboratory Manual. Cold Spring Harbor Laboratory, Cold Spring Harbor, NY.

32. Sanford, J., and Johnston, S. 1985. The concept of pathogen derived resistance: Deriving resistance genes from the parasite's own genome. J. Theor. Biol. 113:395-405.

33. Scorza, R., Levy, L., Damsteegt, V., Yepes, M., Cordts, J., Hadidi, A., Slightom, J., and Gonsalves, D. 1995. Transformation of plum with the papaya ringspot virus coat protein gene and reaction of transgenic plants to plum pox virus. J. Am. Soc. Hortic. Sci. 120:943-952

34. Shukla, D., Frenkel, M., and Ward, C. 1991. Structure and function of the potyvirus genome with special reference to the coat protein coding region. Can. J. Plant Pathol. 13:178191.

35. Slightom, J. 1991. Custom polymerase-chain reaction engineering of a plant expression vector. Gene 100:251-255.

36. Teakle, D., and Pares, R. 1977. Potyvirus (Potato virus Y) group. In: Ultrastructure of Biological Systems. The Atlas of Insect and Plant Viruses. K. Maramorosch, ed. Academic Press, New York.

37. Tennant, P. 1996. Evaluation of the resistance of coat protein transgenic papaya against $\mathrm{Pa}$ paya ringspot virus isolates and development of transgenic papaya for Jamaica. Ph.D. thesis. Cornell University, Ithaca, NY.

38. Tennant, P., Ahmad, M., and Gonsalves, D. 2002. Transformation of Carica papaya L. with virus coat protein genes for studies on resistance to Papaya ringspot virus from Jamaica. Trop. Agric. 79:105-113.

39. Tennant, P., Fermin, G., Fitch, M., Manshardt, R., Slightom, J., and Gonsalves, D. 2001. $\mathrm{Pa}$ paya ringspot virus resistance of transgenic 'Rainbow' and 'SunUp' is affected by gene 
dosage, plant development, and coat protein homology. Eur. J. Plant Pathol. 107:645-653.

40. van den Boogaart, T., Lomonossoff, G., and Davies, J. 1998. Can we explain RNAmediated virus resistance by homologydependent gene silencing? Mol. Plant-Microbe Interact. 11:717-723.
41. Wilson, T., and Watkins, P. 1986. Influence of exogenous viral coat protein on the cotranslational disassembly of Tobacco mosaic virus. Virology 149:132-135.

42. Wisnieswski, L., Powell, P., Nelson, R., and Beachy, R. 1990. Local and systemic spread of Tobacco mosaic virus in transgenic tobacco.
Plant Cell 2:559-567.

43. Yepes, L. M., Fuchs, M., Slightom, J. L., and Gonsalves, D. 1996. Sense and antisense coat protein gene constructs confer high levels of resistance to tomato ringspot nepovirus in transgenic Nicotiana species. Phytopathology 86:417-424. 